\title{
Stage IV Colorectal Cancer AJCC v8
}

National Cancer Institute

\section{Source}

National Cancer Institute. Stage IV Colorectal Cancer A/CC v8. NCI Thesaurus. Code C134195.

Stage IV includes: IVA: (Any T, Any N, M1a); IVB: (Any T, Any N, M1b); IVC: (Any T, Any N, M1c). M1a: Metastasis to one site or organ without peritoneal metastasis. M1b: Metastasis to two or more sites or organs without peritoneal metastasis. M1c: Metastasis to the peritoneal surface alone or with other site or org an metastases. (AJCC 8th ed.) 